\title{
Mergers and acquisitions carried out by Spanish firms in Latin America: a network analysis study ${ }^{1}$
}

\author{
Ángeles Sánchez Díez, Pablo Galaso Reca \\ and José Manuel García de la Cruz
}

\begin{abstract}
This article analyses the changing role played by Spanish firms in foreign investment through mergers and acquisitions in Latin America in 1999-2012. Spanish enterprises that acquired local assets in Latin America and became leading players in the late 1990s have seen the situation change drastically, as new competitors have emerged to undermine Spain's importance as an investor in the region. This study uses the social networks methodology, which enables a more complex analysis than traditional approaches, by studying the position of agents as members of a network being analysed. The use of centrality, density and centralization indicators reveals the structure of the network and how it changes through time, and thus, it shows the relative position of each investor country, Spain in particular.
\end{abstract}

\section{Keywords}

Latin America, foreign investment, Spain, transnational corporations, mergers and acquisitions, competitiveness, telecommunications, power industry, finance, network analysis

JEL classification

F21, F23

\section{Authors}

Ángeles Sánchez Díez is a professor in the Department of Economic Structure and Development Economics at the Autonomous University of Madrid, Spain. angeles.sanchez@uam.es

Pablo Galaso Reca is a research fellow in the Institute of Economics at the Universidad de la República, Uruguay. pgalaso@iecon.ccee.edu.uy

José Manuel García de la Cruz is a professor in the Department of Economic Structure and Development Economics at the Autonomous University of Madrid, Spain. manuel.garcruz@uam.es

\footnotetext{
This article has been produced as part of the research project titled "Spanish investment in Latin America: challenges and opportunities in the context of the Latin American boom and European crisis", directed by Ángeles Sánchez Díez and financed by the Centre of Latin American Studies (CEAL) of the Autonomous University of Madrid. The authors gratefully acknowledge collaboration in data processing from Álex Rodríguez Toscano. All the authors are members of the Study Group on Transformations in the World Economy (GETEM).
} 


\section{Introduction}

Foreign direct investment (FDI) has become one of the core elements of the process of globalization and structural changes in the world economy. This has had a variety of repercussions, such as a redefinition of the new geographical dimensions of political economy, the formation of new power relations between economic agents in the national and international spheres, the increased importance of flows of financial and human capital between countries, or technology transfer. Despite the importance of developed countries as both origins and destinations of investments, developing economies have grown in importance over the last few years. Whereas in 1990, the advanced economies generated 95.3\% of FDI outflows and received $83.1 \%$ of the inflows, over the last 10 years, the developing countries have become the main recipients of foreign investment $(60.8 \%$ of the total in 2013), and their firms are becoming major international investors, accounting for 39\% of total FDI (UNCTAD, undated). This is largely explained by the success of the emerging economies and the decline of the triad formed by the United States, the European Union and Japan. Global transformations are not only occurring in the strictly economic domain, but also in other spaces of power such as the technological, political-diplomatic and military spheres, among others. This has repercussions in both the public (States) and the private spheres (transnationals), raising new problems for the governance of national economies, as summarized by Rodrik (2011) in what he refers to as the political trilemma of the world economy.

This is the international backdrop facing the Spanish economy and its firms, which launched their internationalization process in the mid-1990s and was concentrated geographically in Latin America and sectorally in telecommunications, energy and finance. This is explained by a coincidence in time between two factors: (i) the need for Spanish firms to internationalize their operations as a result of the greater competition fuelled by the deepening of the European internal market (1992) and the creation of the Economic and Monetary Union (1999), and (ii) the financing needs of the Latin American economies to implement the structural reforms imposed following the external debt crisis of the 1980s and 1990s (Sánchez Díez, 2002). The changes that have occurred in the Spanish economy, particularly the privatization of public enterprises and external liberalization, strengthened the ownership advantages of some large national firms; while the opening up of capital accounts, the deregulation of regulated sectors, and privatization processes in many Latin American countries improved that region's location advantages, as described by Dunning (1988 and 1994).

Today, the context in which Spanish firms are investing in Latin America is very different from what they encountered two decades ago, owing to the changes that have occurred both in Spain and in that region. Spain is going through a profound crisis that is having undeniable repercussions on the behaviour of national firms. Although they have not decided to disinvest abroad on a massive scale, they have been forced to reorganize their international assets. Moreover, Latin America has achieved high rates of economic growth, sustained by the dynamism of domestic demand and that of emerging countries, in a framework of macroeconomic stability and consolidated public-sector accounts. Accordingly, many countries have designed more sophisticated policies to attract foreign investment, prioritizing "quality" over "quantity," while some Latin American firms have themselves started to internationalize.

In view of this new scenario, this article analyses the investor status of Spanish firms in Latin America and how this has altered as a result of the changes described above. The countries whose investments are analysed are: Argentina, the Bolivarian Republic of Venezuela, Brazil, Chile, Colombia, Costa Rica, Cuba, Ecuador, El Salvador, Guatemala, Honduras, Mexico, Nicaragua, Panama, Paraguay, Peru, the Plurinational State of Bolivia and Uruguay, within the region; and China, France, Germany, Italy, Japan, the United Kingdom, the United States and the countries of the BENELUX economic union (Belgium, the Netherlands and Luxembourg), outside the region. 
The aims of this article are as follows:

- $\quad$ Aim 1: to study the dynamics of business mergers and acquisitions in Latin America in 1999-2012, particularly in terms of the degree of interaction between countries and their geographical concentration.

- $\quad$ Aim 2: to evaluate the role played by Spanish firms in mergers and acquisitions in Latin America, compared to their potential competitors, observing their trend over the period studied. This will make it possible to examine whether or not Spain is losing the leadership position it attained in the second half of the 1990s. In terms of network analysis, the study will detect whether a shift is occurring from central positions to more peripheral ones.

- $\quad$ Aim 3: to analyse the dynamics of mergers and acquisitions in the telecommunications, energy and finance sectors. The aim here is to elucidate whether there are significant differences arising from the different economic activities and identify the position held by Spanish firms in each sector.

To address these aims, the social network analysis methodology was chosen for its great capacity to explain economic independencies, as evidenced in several previous research studies. Network analysis makes it possible to systemically study the complex dynamics of interaction, influences and interdependencies between countries, going beyond the financial data on business mergers and acquisitions in Latin America.

Following this Introduction, section II reviews theoretical work on foreign direct investment and the application of social network analysis to the study of international economic relations. Section III describes the key methodological aspects of the construction, interpretation and analysis of merger and acquisition networks. Section IV analyses the network of mergers and acquisitions among firms in Latin America and the position occupied by Spain compared to its competitors, presenting a dynamic study of 1999-2012, and a static study of the telecommunications, energy and finance sectors. Lastly, section $\mathrm{V}$ sets out the conclusions of this article.

\section{Theoretical aspects of mergers and acquisitions and social network analysis}

Dunning $(1977,1979,1980$ and 1988) summarized the contributions made by different authors to the study of FDI in the so-called "eclectic" paradigm, indicating that FDI would take place in the presence of advantages in terms of ownership, the location of the destination country ${ }^{2}$ and internalization (which is known as the OLI model or paradigm). From the industrial organization school, he drew on contributions by Hymer (1976 and 1979), Kindleberger (1969), Caves (1971, 1980 and 1982) and Caves and Hirschey (1981), which gave rise to "ownership advantages," in other words specific capacities that multinational enterprises have in terms of exclusive ownership compared with local firms. Nonetheless, while necessary, ownership advantages are not sufficient for a company to invest abroad. This requires the presence of a location advantage in the destination country, an element that is analysed by location theories. The contributions of internalization theory were included as well, specifically those by Williamson (1975), Casson (1979 and 1985), Rugman (1976, 1980 and 1981) and Tecee (1986), who started from the hypothesis that enterprise internationalization is a mechanism for reducing the transaction costs arising from imperfectly functioning markets.

The criticisms that have been levelled against the OLI paradigm include the fact that it cannot clearly explain investment originating in developing countries, since most of those countries' firms do

\footnotetext{
2 Later, the importance of location factors in the countries of origin of the transnational firms started to be analysed. See Dunning (2009), among others, on theoretical contributions, and also Álvarez and Torrecillas (2013) for empirical evidence.
} 
not have exclusive ownership advantages. According to Moon and Roehl (2001), the transnational enterprises of emerging countries pursue their own strengthening with their internationalization, by accumulating resources and assets to which they previously did not have access. Even Dunning himself (2009) has nuanced his theoretical reflections, by arguing that the pursuit of knowledge and learning experiences could be motivating internationalization among firms from those countries, in the absence of the classic ownership advantages - an idea previously put forward by Luo and Tung (2007). In short, the international expansion of developing-country firms can be interpreted in the light of the analytical framework known as linkage, leverage and learning (the LLL model) (ECLAC, 2014; Mathews, 2006), whereby the firms make a variety of alliances to gain access to resources that were previously unavailable to them. Thus, firms that start later in the internationalization process, can take advantage of other firms' experience and knowledge.

Nonetheless, it is clear that the reception of foreign firms represents an opportunity for domestic firms to appropriate the externalities that foreign investments generate in the destination economies. This can improve their location attraction for future investments, as argued in the OLI paradigm; but it can also encourage domestic enterprises to embark on internationalization strategies themselves, as suggested by the LLL model.

For these reasons, and despite this being a controversial topic, ${ }^{3}$ two assumptions are made:

(i) The presence of transnational enterprises in a given economy can result in changes to the production fabric, through spillover effects (Aitken and Harrison, 1999): a merger or acquisition can result in certain ownership advantages being transferred to the acquired local asset. These transfers are understood as flows of information, knowledge, learning on modes of organization, human capital, financing and technology. The economy acquiring assets abroad can also receive spillover effects in the form of knowledge flows, new business practices or human resources.

(ii) Transnational enterprises can encourage domestic firms to modernize their production and training processes and upgrade the quality of their production (Blomström and Kokko, 2003). Owing to spillover effects, the two countries participating in a cross-border operation can obtain specific benefits from these relations with an impact on their economic structures. ${ }^{4}$

Given that countries, through their firms, tend to engage in merger and acquisition operations with several countries, the aforementioned spillover effects ultimately occur multilaterally, as shown in diagram 1.

\section{Diagram 1}

Example of multilateral spillovers in cross-border merger and acquisition operations

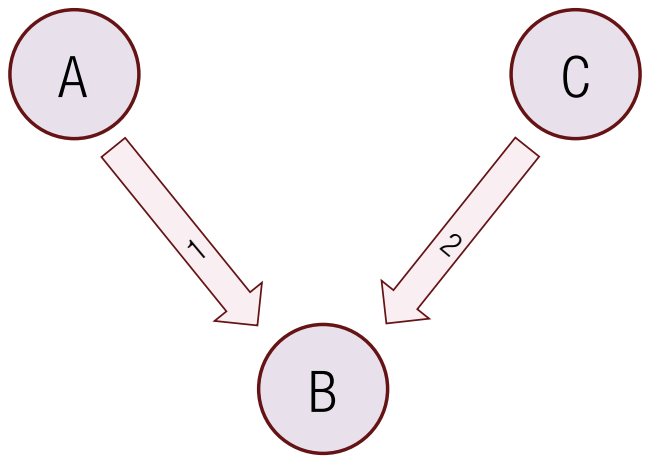

Source: Prepared by the authors.

\footnotetext{
3 For a summary of positions on this topic, see box I.1 of ECLAC (2011, p. 29).

4 The dissemination of the benefits and their structural impact will not be automatic or necessarily direct; and the benefits will not necessarily occur in all merger or acquisition operations. Public policies are decisive in determining the final outcomes.
} 
Link 1 represents acquisitions made by firms in country $A$ of businesses in country $B$, which involves a foreign direct investment flow from $A$ to $B$. Link 2 reflects the same process between countries $B$ and $C$. The operations represented in link 1 can generate transformations in countries $A$ and B; but these could also occur in country $\mathrm{C}$ through Link 2. In other words, spillovers of information, knowledge, organizational learning, human capital, financing and technology are not exclusively confined to direct links between two countries, but circulate between them through multiple interactions, under a network logic. It is therefore essential to simultaneously consider the set of relations that exist between countries to gain an adequate understanding of the flows in question.

As noted above, cross-border mergers and acquisitions are analysed using the social networks methodology, so the characteristics of the individual social units will be viewed as arising out of structural or relational processes (Wasserman and Faust, 1994, p. 7). Broadly speaking, studies on this methodology include theoretical analyses of the formation and evolution of networks (Watts and Strogatz, 1998; Jackson and Wolinsky, 1996), empirical studies on the structures and patterns of networks in the real world (Bearman, Moody and Stovel, 2004; Fagiolo, Reyes and Schiavo, 2009) and methodological analyses that provide new research tools (Wasserman and Faust, 1994; Jackson, 2008).

In economics, this methodology has been used to analyse the structure and functioning of competitive markets (Mitchell and Skrzypacz, 2006; Amir and Lazzati, 2011), employment and wage inequality (Calvó-Armengol and Jackson, 2004), the dissemination of information and innovations (Schilling and Phelps, 2007; Fleming, King and Juda, 2007; Galaso, 2011) and the patterns governing international trade (Kali and Reyes, 2006; De Benedictis and others, 2013).

There is also a growing academic literature that uses network analyses to study international financial flows in general, although its application to the analysis of foreign investment is still relatively incipient. Some studies have focused on analysing international financial crises (Chinazzi and others, 2013; Elliott, Golub and Jackson, 2014), and the shareholding structures of transnational enterprises (Vitali, Glattfelder and Battiston, 2011; Vitali and Battiston, 2013). In contrast, Haberly and Wojcik (2013) focus on the FDI network originating in tax havens, and show a heavy concentration of flows and high level of dependency on political and social similarities between countries, while Visintin (2011) analyses the international networks of trade and FDI, which display a hub-and-spoke structure.

\section{Methodology: construction and analysis of merger and acquisition networks}

The following paragraphs detail the methodological aspects of constructing networks applied to the case of cross-border mergers and acquisitions, and the analysis of the results obtained.

\section{Construction of the networks}

In this case, applying this methodology requires a double-entry matrix of the economic flows that took place between pairs of countries in 1999-2012. As there is no information at the global level on FDI by origin and destination, or by sector, for all countries, it was decided to construct the matrix from the database on cross-border mergers and acquisitions prepared by Thomson Reuters. The following have been calculated: 1 matrix and 1 network covering the entire period and all sectors; 7 biennial matrices and 7 biennial networks (except for one case in which they are triennial and which corresponds to just one year, the end of the period); and 3 sectoral matrices and 3 sectoral networks. In other words, a total of 11 matrices and 11 networks have been calculated, along with their associated indicators. 
The entire network requires two basic elements: nodes and links. In this analysis, the nodes correspond to the 28 national economies covered by the study, as mentioned above; and the links between the nodes represent the total value (in millions of dollars) of the purchases made by the firms of one country of those in another. From the database used, all operations were selected in which at least one of the two firms involved - either the buyer or the seller - is located in a Latin American country. In other words, relations between two non-Latin American economies were not included. ${ }^{5}$

Table 1 shows a simplified example of the database, with three operations between firms belonging to two countries. By aggregating these operations, the values of the links connecting the countries are calculated as shown in diagram 2.

Table 1

Sample of the database used to construct the networks of business cross-border mergers and acquisitions

\begin{tabular}{cccccc}
\hline \multicolumn{2}{c}{ Buyer } & & \multicolumn{2}{c}{ Seller } & \multirow{2}{*}{ Size of the operation } \\
\cline { 1 - 2 } Firm & Country & & Firm & Country & \\
\hline 1 & A & & 2 & B & 100 \\
\hline 3 & A & 4 & B & 50 \\
\hline 5 & B & 6 & A & 200 \\
\hline
\end{tabular}

Source: Prepared by the authors.

Diagram 2

Example of two links between countries in business merger and acquisition operations
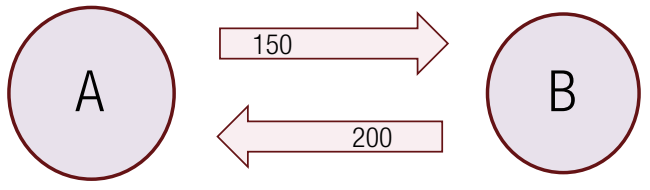

Source: Prepared by the authors.

Once the links are identified, their direction and weights are analysed. The direction depends on where the buying and selling firms are located. Diagram 2 shows a link that runs from $A$ to $B$ and another that goes from $B$ to $A$. Having directed links makes it possible to distinguish between inflows and outflows, and this broadens the options for calculating and interpreting the network indicators. Accordingly, this is a directed network or graph, in which the links can be analysed in both directions. The weight corresponds to the total value of the purchases made by the firms of one country of those in another. Thus, in diagram 2, the weight of the link running from $A$ to $B$ is 150 , representing the sum of mergers between firms 1 and 2, on the one hand, and 3 and 4 , on the other. Similarly, the link that runs from $B$ to $A$ has a value of 200 , equivalent to the merger between firms 5 and 6 . This makes it possible to identify the most important links in the network and those that are less important. Simultaneously tracing all of the links between the 28 countries defines the full network of business mergers and acquisitions in Latin America.

\footnotetext{
5 For example, this analysis includes a purchase of Colombian asset by a French firm, and vice versa, as well as the acquisition of a Chilean company by a Brazilian firm; but it excludes operations between French and Spanish enterprises.
} 


\section{Network analysis}

To study the dynamics of enterprise mergers and acquisitions in Latin America (aim 1) the full network is analysed, which includes data for all years and the seven time-framed networks. These networks are studied from a global perspective, that is, using indicators that describe the structure of the network as a whole, without distinguishing the position occupied by each country. Specifically, it uses indicators of density and total degree centrality, which measure structural properties relating to the patterns of collective interaction between all of the countries included. These indicators are interpreted as follows:

- Density measures the proportion of links existing in a network relative to the maximum possible number, ${ }^{6}$ and thus quantifies the degree of connection between actors. In this study, it is used to measure the overall level of interaction between countries.

- The total degree centrality indicator measures concentration in the distribution of links between network nodes, in other words the concentration of merger and acquisition operations between countries. This makes it possible to quantify whether these operations are concentrated among just a few countries that channel resources, accumulate spillover effects and exert their influence on the rest; or, on the contrary, whether the merger and acquisition links are established in a relatively distributed way, with the participation of multiple centres of action.

The role played by Spain is then analysed, along with its evolution during the period studied, both in the full network of data from all years and in the seven time-framed networks (aim 2). The study is conducted using indicators that describe the relative position occupied by each country in the networks. In particular, four measures of centrality are calculated: in-degree, out-degree, total degree, and eigenvector. These are defined as follows:

- $\quad$ Degree centrality corresponds to the number of links that a node has, weighted by the value of each link. In other words, it is the number of connections a country maintains with the other countries in the network, weighted by the value, in millions of dollars, of the operations that these connections represent. In directed graphs (such as those used in this analysis) three different measures of degree centrality can be defined: in-degree, out-degree and total. Their calculation is analogous, but it is done by considering the links flowing into the node, those flowing out of it, and the sum of the two, respectively. These represent the volume of investment received by the country through sales of its firms to foreign companies (in-degree centrality); the outward investment by the country's firms in payment for assets purchased abroad (out-degree centrality); and the combination of the two (total degree centrality).

- Eigenvector centrality (Bonacich, 1972) measures the influence capacity of a node, in this case a country. Nodes (countries) with high values of this indicator are linked to others which are also well connected, so they are in a position to exert influence, disseminate information or propagate spillover effects.

Lastly, the aim of studying the telecommunications, energy and finance sectors (aim 3) requires the use of sectoral networks to calculate all of the foregoing indicators. This makes it possible to analyse both the patterns of collective interaction between countries and the relative position of Spain in the three selected sectors.

Table 2 provides greater detail of the relation between the aims of this study, the associated economic concepts, the network indicators to be used for the analysis, and how they are calculated.

6 The maximum number of links is attained when at least one firm in each of the 28 countries considered purchases a firm in each of the other 27 countries. 
Table 2

Main network indicators proposed for the analysis

\begin{tabular}{|c|c|c|c|}
\hline $\begin{array}{l}\text { Aims of } \\
\text { the article }\end{array}$ & Associated economic concept & Network indicatora & Calculation ${ }^{b}$ \\
\hline \multirow[b]{2}{*}{1 and 3} & $\begin{array}{l}\text { Interaction between the } \\
\text { countries in business merger } \\
\text { and acquisition processes }\end{array}$ & Density & $\begin{array}{l}D=\frac{V}{\max (V)} \\
\text { where } V \text { is the number of links existing in the network and } \\
\max (V) \text { is the maximum number of links that could exist } \\
\text { in the network if all nodes were linked to all others. }\end{array}$ \\
\hline & $\begin{array}{l}\text { Geographical concentration } \\
\text { of business mergers } \\
\text { and acquisitions }\end{array}$ & $\begin{array}{l}\text { Total degree } \\
\text { centrality }\end{array}$ & $\begin{array}{l}C G T=\frac{\sum_{u=1}^{u=|N|} C G_{\text {tot }}\left(u^{*}\right)-C G_{\text {tot }}(u)}{\max \left(\sum_{u=1}^{u=|N|} C G_{\text {tot }}\left(u^{*}\right)-C G_{\text {tot }}(u)\right)} \\
\text { where } N \text { is the number of nodes in the network } u \text { represents } \\
\text { a given network node, } C G_{t o t}(u) \text { is the total degree } \\
\text { centrality of node } u \text { and } C G_{\text {tot }}\left(u^{*}\right) \text { is the maximum } \\
\text { total degree centrality registered by a network node. }\end{array}$ \\
\hline \multirow{4}{*}{2 and 3} & \multirow[t]{2}{*}{$\begin{array}{l}\text { Relative importance of a } \\
\text { country in the region's business } \\
\text { mergers and acquisitions }\end{array}$} & $\begin{array}{l}\text { Total degree } \\
\text { centrality }\end{array}$ & $\begin{array}{l}C G_{\text {tot }}(u)=\sum_{v=1, v \neq u} w_{v, u}+\sum_{v=1, v \neq u} w_{u, v} \\
\text { where } N \text { is the number of nodes in the network, } \\
v \text { represents a given node of the network, } W_{v, u} \text { is the } \\
\text { value of the link running from node } v \text { to node } u \text { and } W_{u, v} \\
\text { is the value of the link running from node } u \text { to node } v \text {. }\end{array}$ \\
\hline & & $\begin{array}{l}\text { Eigenvector } \\
\text { centrality }\end{array}$ & $\begin{array}{l}\lambda C V P=W \cdot C V P \\
\text { where } W \text { is the adjacency matrix, i.e. the square } \\
\text { matrix that represents all network links, and } \lambda \text { is the } \\
\text { maximum eigenvalue of the adjacency matrix. }\end{array}$ \\
\hline & $\begin{array}{l}\text { Relative importance of a } \\
\text { country in the region's } \\
\text { mergers and acquisitions } \\
\text { (by purchasing firms) }\end{array}$ & $\begin{array}{l}\text { Out-degree } \\
\text { centrality }\end{array}$ & $\begin{array}{l}C G_{\text {sal }}(u)=\sum_{v=1, v \neq u} w_{u, v} \\
\text { where } N \text { is the number of nodes in the network, } v \text { represents a } \\
\text { given node of the network, and } W_{u, v} \text { is the value of the link } \\
\text { running from node } u \text { to node } v \text {. }\end{array}$ \\
\hline & $\begin{array}{l}\text { Relative importance of a country } \\
\text { in the region's mergers and } \\
\text { acquisitions (by firms purchased) }\end{array}$ & In-degree centrality & $\begin{array}{l}C G_{\text {ent }}(u)=\sum_{v=1, v \neq u}^{|N|} w_{v, u} \\
\text { where } N \text { is the number of nodes in the network, } v \\
\text { represents a given node of the network, and } W_{v, u} \text { is the } \\
\text { value of the link running from node } v \text { to node } u \text {. }\end{array}$ \\
\hline
\end{tabular}

Source: Prepared by the authors.

a The density and centralization indicators reveal general characteristics of the network, whereas the degree centrality indicators (total, in and out) and the eigenvector centrality indicator make it possible to observe the position of a node (country) in the network.

b The centrality indicators are normalized by dividing them by the maximum possible value.

\section{Results of the network analysis on mergers and acquisitions in Latin America}

The following paragraphs report the results of the network analysis of mergers and acquisitions among firms in Latin America between 1999 and 2012. Firstly, the general dynamics of mergers and acquisitions in the region are studied; later, the role played by Spain is analysed, and lastly, the analysis focuses on the telecommunications, energy and finance sectors. 


\section{The dynamic of mergers and acquisitions in Latin America}

The structural properties of the global network are firstly analysed for the years studied (see figure 1 and table 3), focusing on the degree of interaction between countries (density) and the geographical concentration of this type of operation in the region (centralization). The results reveal two key features:

- The degree of interaction between countries, measured by the network density indicator, is highest in two periods, 2007-2009 and 2010-2011. This reflects a major change in the reorganization of productive assets in Latin America. In the late 1990s and early 2000s, business acquisitions in the region were undertaken by companies from just a few countries. Spanish firms, in particular, took advantage of the privatization processes that were unfolding in the vast majority of Latin American countries. Nonetheless, the reality of the region changed rapidly. The strengthening of Latin American firms and the boom in their operations abroad have increased the degree of interaction between the countries of the region, particularly considering that the vast majority of trans-Latin enterprises have their foreign assets located elsewhere in Latin America itself. Chinese firms are also displaying increasing interest, with a very aggressive dynamic in terms of natural resource extraction; while United States companies have always been present in the region, albeit in cycles.

- In terms of the geographical concentration of mergers and acquisitions, the total centralization indicator is at a maximum in 2007-2009, which shows that the large number of merger operations, revealed in the increase in density, progressively tended to concentrate in fewer countries. Moreover, as from 2010, this indicator remains above the levels recorded in the first half of the 2000 decade, which shows that merger and acquisition opportunities since the international financial crisis are being exploited by fewer countries. In other words, this reflects a trend towards a network structure in which most countries are relatively marginalized from cross-border business merger and acquisition operations, while just a few account for most of the investment inflows and outflows.

Figure 1

Latin America: network of cross-border business mergers and acquisitions, 1999-2012

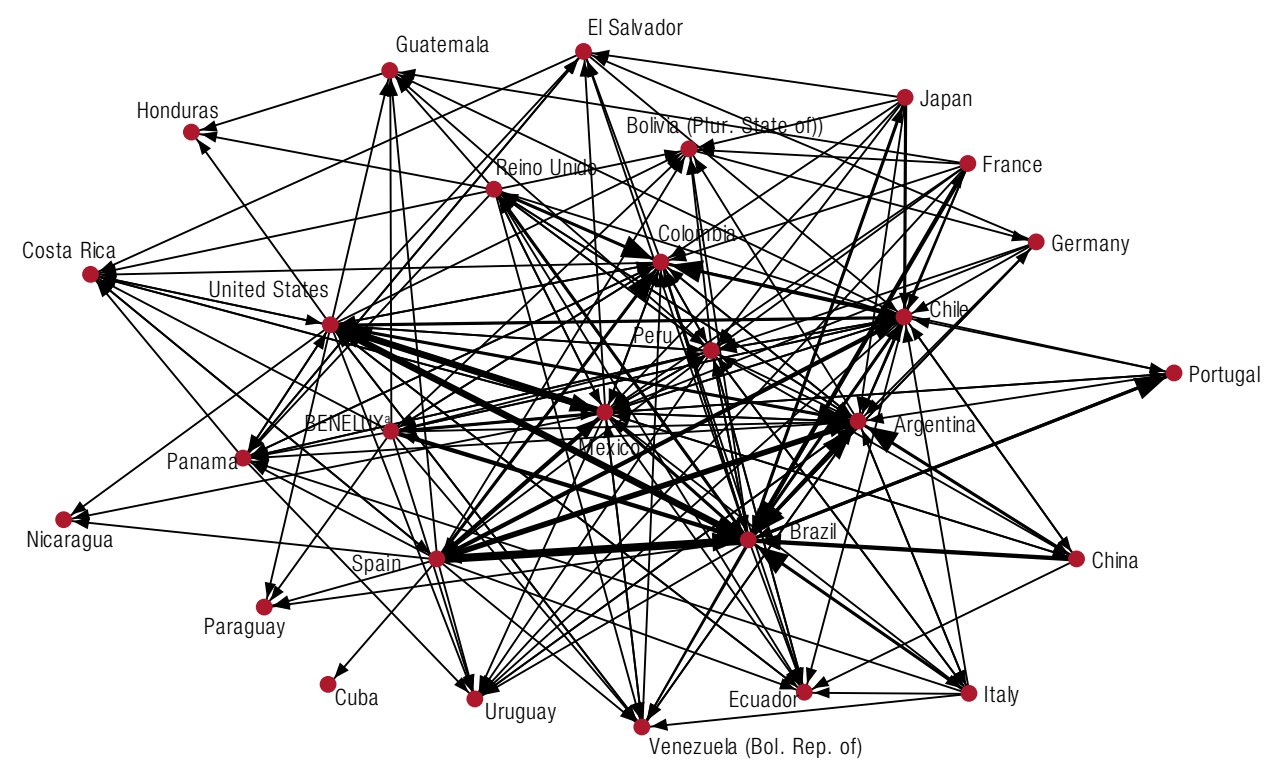

Source: Prepared by the authors on the basis of data from Thomson Reuters.

a Economic union between Belgium, the Netherlands and Luxembourg. 
Table 3

Latin America: structural characteristics of the network of cross-border business mergers and acquisitions, 1999-2012

\begin{tabular}{lccccccc}
\hline & $1999-2000$ & $2001-2002$ & $2003-2004$ & $2005-2006$ & $2007-2009$ & $2010-2011$ & 2012 \\
\hline Density & 0.118 & 0.101 & 0.091 & 0.106 & 0.159 & 0.143 & 0.081 \\
\hline Total degree centrality & 0.044 & 0.03 & 0.038 & 0.050 & 0.106 & 0.073 & 0.051 \\
\hline
\end{tabular}

Source: Prepared by the authors.

\section{The role of Spain in mergers and acquisitions in Latin America}

The analysis now focuses on the role played by Spain in the network of business mergers and acquisitions in Latin America, by studying its position relative to the other countries (nodes) of the network. Special attention is paid to the comparison with countries that have been very active in recent years, such as Brazil, China and the United States.

The total degree centrality indicators by country (see figure 2) show that there is a small group of countries with high levels of centrality, and a large number of countries that occupy more peripheral positions - in other words, countries with weaker merger and acquisition flows (links) with the rest. The situation of the most central countries shows that their firms have established contacts, through mergers and acquisitions, with firms in a wide range of countries, whether as buyers (out-degree centrality) or as bought (in-degree centrality).

Figure 2

Selected countries: degree centrality indicators in cross-border business mergers and acquisitions, 1999-2012

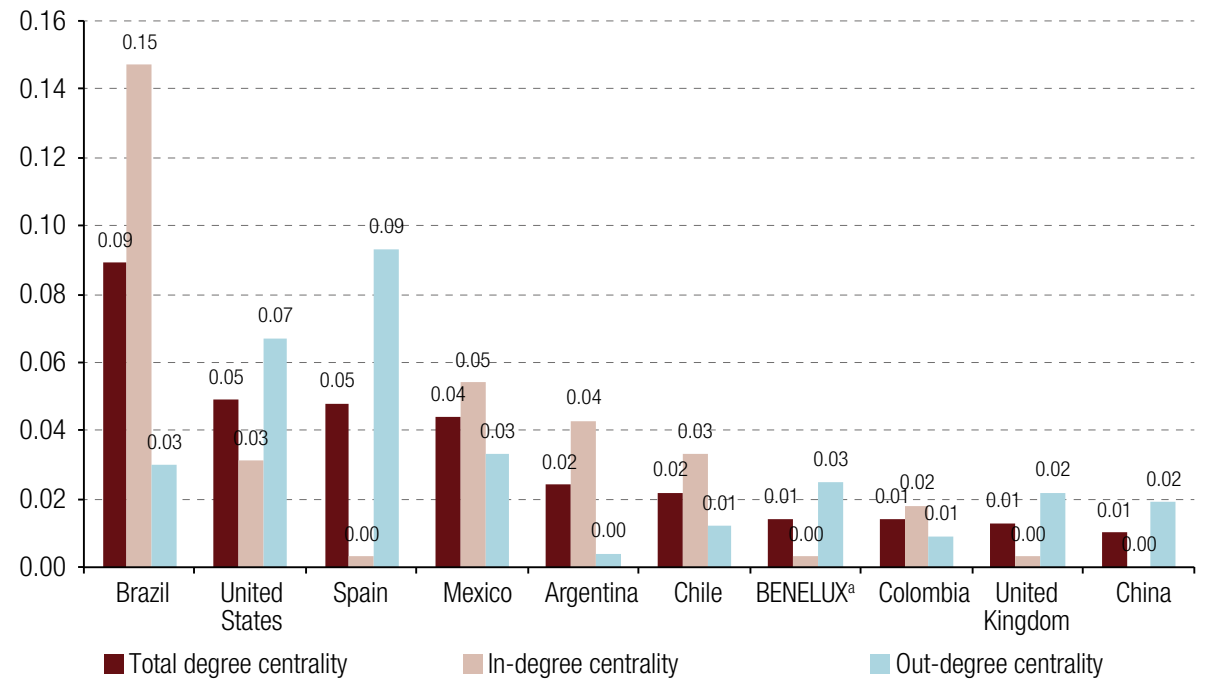

Source: Prepared by the authors.

a Economic union of Belgium, the Netherlands and Luxembourg.

In the entire period studied, the leading players are Brazil, Spain, the United States and, to a lesser extent, Argentina, Chile and Mexico. These are the economies which, from a global standpoint, are at the centre of the network (according to the total degree centrality indicator) maintaining most interactions with all agents participating in the network. There are significant differences between 
them, however, particularly in terms of their differentiated position as countries of origin of the firms buying or selling assets. Given the assumptions, these economies are the most important in terms of their potential to channel spillover effects (Aitken and Harrison, 1999) -in other words their potential to facilitate flows of information, knowledge, organizational learning, human capital, financing and technology. They also display greater possibilities for modernizing their production processes, training and location in production (Blomström and Kokko, 2003), and for generating changes in their economic structures.

Spain and the United States, followed by Brazil, Mexico and the BENELUX countries (Belgium, the Netherlands and Luxembourg) are more dynamic in terms of the internationalization of their firms, as shown by their higher out-degree centrality indices. Spain's central role stems from its seizing the purchase opportunities generated by the 1990s privatization processes, and in the subsequent reorganization of assets and expansion of its companies' investments in the region, to consolidate their leadership and exploit a market that was already known to them. Although the entrepreneurial drive of Spanish companies has never faded, it was less intensive in the periods 2001-2002 and 2005-2006, when these firms retargeted their foreign operations towards the European market, while taking advantage of the experience and size they had acquired in Latin America. Spanish firms have to some extent reproduced their parent companies in their Latin American branches, which have been created through local takeovers (ECLAC, 2003 and 2012).

The United States, which was a major investor throughout the twentieth century, has continued to make large-scale purchases of productive assets in Latin America, as shown by its levels of out-degree centrality, which rose in the two years leading up to the crisis. This indicator has risen substantially also in the case of Brazil, reflecting the boom in the international expansion of its firms since the middle of the 2000 decade (ECLAC, 2005 and 2014). Brazilian trans-Latin companies are favoured by the substantial support policy applied by the public sector, in particular that carried out by the Brazilian Development Bank (BNDES). For its part, Mexico has held positions of greater out-degree centrality in the network, particularly in the period prior to the 2009 recession.

In terms of a country's attractiveness as an investment destination, Brazil and Mexico, and to a lesser extent Argentina and Chile, are the leaders. These economies have implemented farreaching structural reforms that have made it easier for foreign firms to enter their economies and be profitable. In addition, both Brazil and Mexico have large domestic markets, a fact that appears to be an important location advantage for foreign investors. Nonetheless, the differences over the period are significant. Argentina's position deteriorated sharply, from high in-degree centrality in the late 1990s to very low levels in the latter years of the period analysed. The uncertainty triggered by the end of convertibility in 2001, which resulted in numerous disputes being brought before the International Centre for Settlement of Investment Disputes (ICSID) (Stanley, 2004; Zabalo Arena, 2012), caused a fall in centrality levels from which the country has not yet recovered during the twenty-first century (see figure 2).

The relatively low levels of in-degree centrality displayed by the United States and Spain are not surprising, because the way the network has been constructed means that only the acquisitions made by Latin American firms of Spanish or United States companies are included. This shows that transLatin firms are still relatively inactive in terms of expanding outside the region.

Another approach is to analyse a country's degree of connectedness with the most influential actors in the network, through eigenvector centrality. Brazil and Spain, followed by the United States, Mexico and Argentina, are the countries with the highest eigenvector centrality, since the transfer of information and knowledge, changes in modes of business organization, human resources, availability of information and, in general, the concentration of power revolve around those countries (see figure 3). 
An analysis through time highlights the progressive loss of influence of countries such as Mexico or the United Kingdom, as measured by eigenvector centrality. Another key feature is the sudden emergence of China which, having been absent throughout the period, in 2010-2011 achieved a centrality level ahead of Spain, to rank second behind Brazil.

Figure 3

Selected countries: eigenvector centrality in cross-border business mergers and acquisitions, 1999-2012

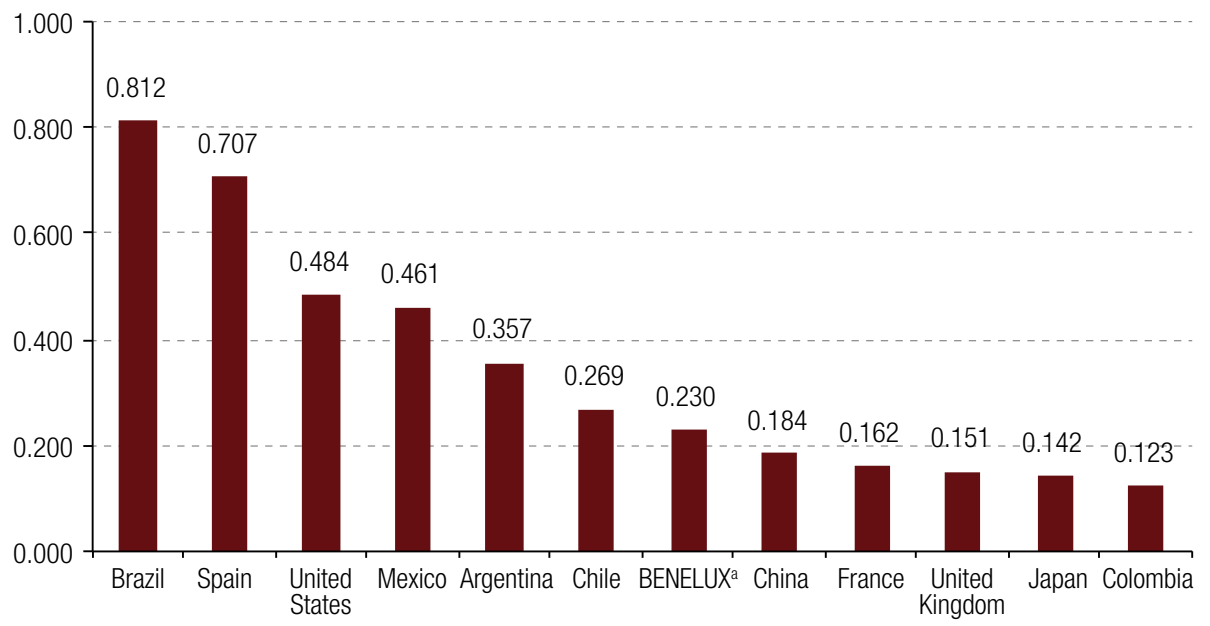

Source: Prepared by the authors.

a Economic union of Belgium, the Netherlands and Luxembourg.

Accordingly, despite the increase in the overall centralization of the network (largely owing to the role of Brazil), other centers of information exchange and dynamism in the transfer of experiences, learning, technology and other factors have emerged during this period, aside from the traditional players such as Spain, United States or Mexico. Economies as diverse as Colombia, Chile and China have started to gain relative importance in the interactions studied.

\section{Mergers and acquisitions in the telecommunications, energy and finance sectors: regional dynamics and the role of Spain}

When mergers and acquisitions are classified by the sectors of production in which the firms operate, a differentiated analysis reveals the behaviour patterns pertaining to each sector. In this case, the services sectors in which Spanish transnational companies have been most dynamic in Latin America were selected, namely telecommunications, energy and finance (see table 4 and figure 4).

Table 4

Latin America: structural characteristics of the networks of cross-border business mergers and acquisitions, selected sectors

\begin{tabular}{lcccc}
\hline & Energy & Finance & Telecommunications & Global \\
\hline Density & 0.104 & 0.108 & 0.066 & 0.279 \\
\hline Total degree centrality & 0.036 & 0.040 & 0.032 & 0.081 \\
\hline
\end{tabular}

Source: Prepared by the authors. 
Figure 4

Latin America: networks of cross-border business mergers and acquisitions, selected sectors, 1999-2012

\section{A. Energy}

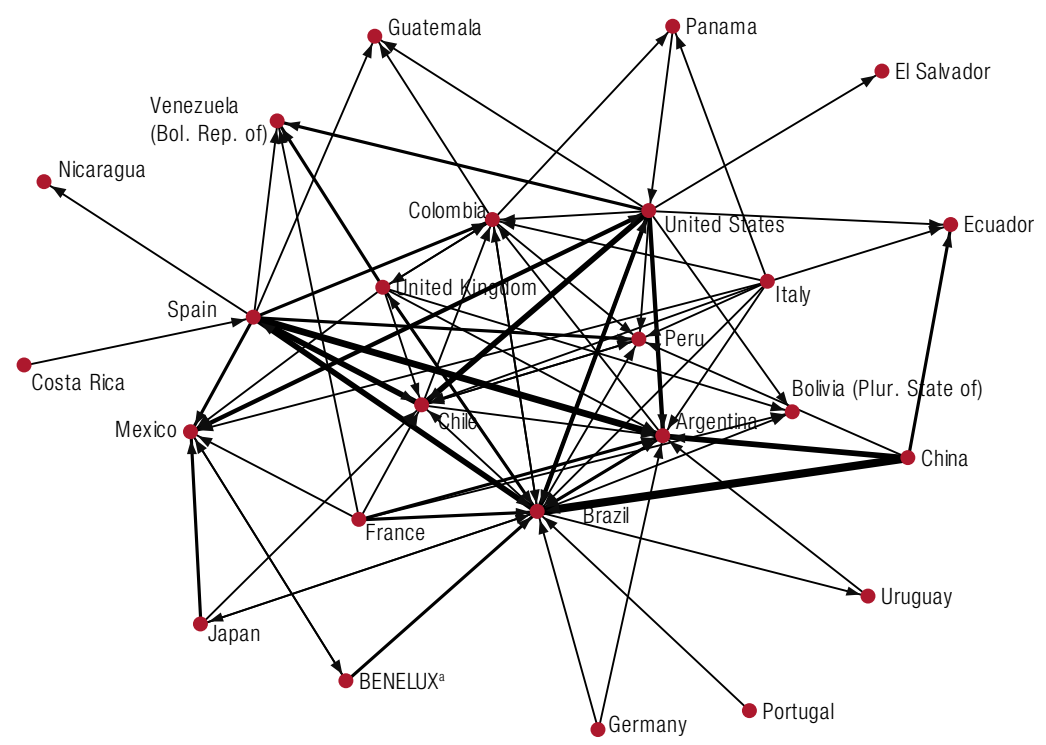

B. Finance

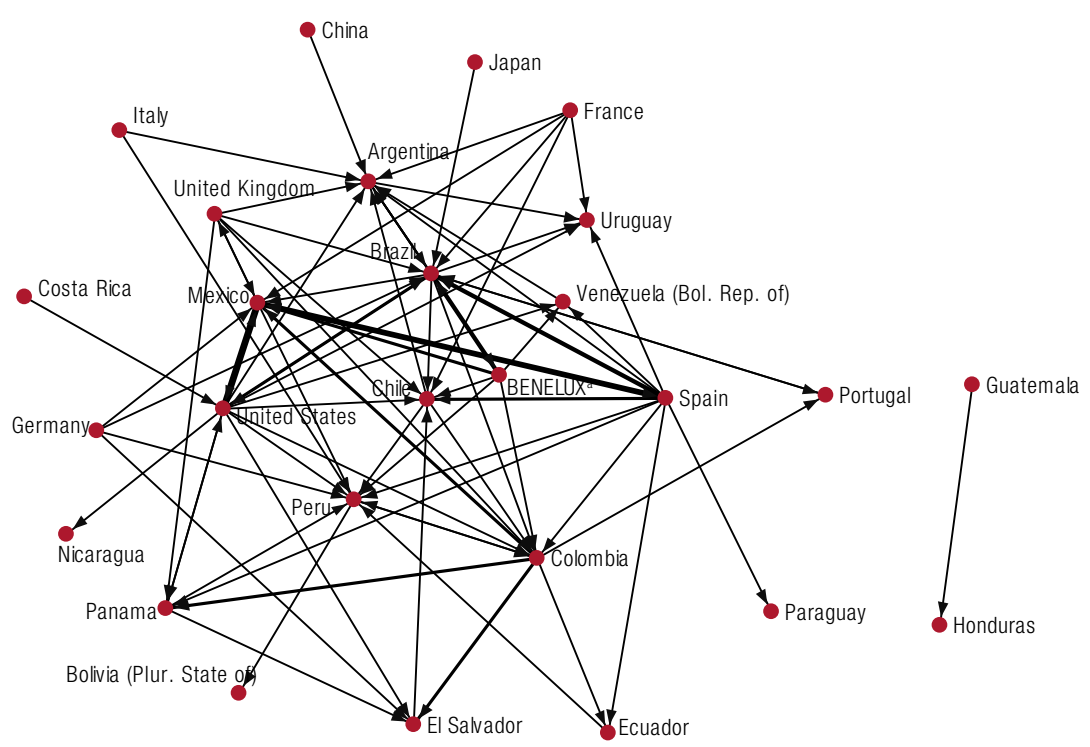


Figure 4 (concluded)

\section{Telecomunications}

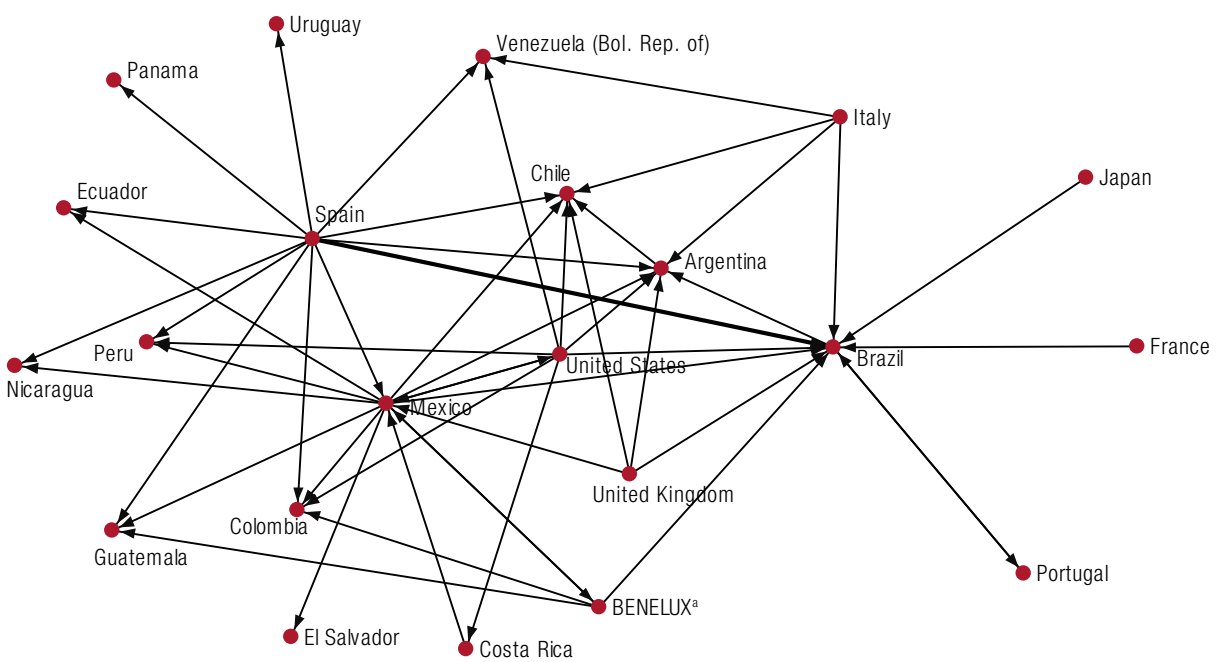

Source: Prepared by the authors.

a Economic union of Belgium, the Netherlands and Luxembourg.

The analysis of the structural characteristics of these networks (see table 4) leads to the following conclusions:

- $\quad$ The interaction between countries, as measured by density, is greatest in the energy and finance sectors, and least in the telecommunications sector. Whereas many banking and energy firms have been set up in Latin America, the telecommunications market is basically controlled by two large operators.

- The sectoral networks display lower concentration levels, as measured through centralization, than those of the total network. This means that the mergers and acquisitions in the energy, telecommunications and finance sectors involve a larger number of active countries, since most countries have liberalized those public utility sectors to permit the entry of foreign-owned companies, which have set up businesses in those economies by purchasing existing assets.

In each of the sectors considered, it is possible to discern Spain's position relative to all countries, and with respect to those with which it disputes the most influential positions, particularly Brazil and the United States -although there are specific features in each sector.

In the energy sector, Spain has been more active than the United States and Brazil in acquiring Latin American firms, as measured by out-degree centrality. Companies such as Empresa Nacional de Electricidad, S.A. (ENDESA), now owned by the Italian firm ENEL, along with Iberdrola, Gas Natural and Unión Fenosa - the last two now merged as Gas Natural Fenosa- have expanded vigorously in the region. In the 1990s, these firms started to change their business structure to adapt to the legislative changes arising from the liberalization of the electricity and gas sectors imposed by the European Union. This meant not only operating in a climate of competition, but also vertically separating the generation, distribution and marketing segments. In addition, new technological developments associated with the generation of electricity through combined-cycle turbines linked the electricity and gas businesses. The final outcome was a process of mergers and acquisitions in the national markets, followed by their international expansion. At the same time, regulatory frameworks in the electric power sector in Latin America were altered, although with differences between countries (Maldonado and Palma, 2004). In this context, the Spanish firms acquired major assets in the region, competing with a number of United States enterprises such as Enron and AES Corporation, which had begun 
their operations in the region a decade earlier. The energy crisis in California and the bankruptcy of Enron in 2001 cleared the path for Spanish firms and other European enterprises, while also opening up space for Latin American firms themselves. Nonetheless, the regulatory frameworks prevailing in Latin America have generated major uncertainties and regulatory risks (ECLAC, 2004), so some of the larger or faster-growing economies currently pose major energy-security challenges.

With regard to eigenvector centrality in the energy sector, Spain has been slightly overtaken by Brazil in the position of central country (node) although it is well ahead of the United States. As explained above, this indicator shows the connection with other countries (nodes) that are central in the network. It should be recalled that while Brazil privatized assets in the energy distribution and transmission segments, its privatization of the generating companies was interrupted by the energy crisis of 2001-2002 (ECLAC, 2012). In addition, several Brazilian public enterprises have crossed borders, such as Petróleo Brasileiro (Petrobras), which, along with Gas Natural Fenosa, is also one of the few companies in the region to show significant levels of integration between electric power generation and natural gas activities.

In the financial sector network, Spain stands out as an asset-purchasing country, according to the out-degree centrality measure, which puts it ahead of both the United States and Brazil. The Spanish banks have purchased numerous assets as they found a market in Latin America for the expansion of their activities. ${ }^{7}$ Moreover, those investments enabled them to exploit their resources and organizational and technological capacities in a global way, thus diversifying risk (ECLAC, 2012). Entities such as Banco Santander and Banco Bilbao Vizcaya Argentaria (BBVA) are present in nearly all countries, having entered by taking over national banks. Although the penetration models of the two entities were different, there are several common features, such as the search for a potentially very broad market, since banking services are much less widely used in Latin American countries than in Spain and other countries of the European Union (Sánchez Díez, 2002). The lower in-degree centrality of Brazil can be explained by the importance of the public banking sector and local groups, which have made it difficult for foreign banks to enter the market. Regional competitors (both Colombian and Brazilian) have also appeared, however, along with European ones (British and Dutch), which are gaining substantial penetration in the region.

The analysis of eigenvector centrality in the financial sector shows that Spain has a more peripheral position than the United States, reflecting the historical presence of American banks in the region, which have maintained and consolidated their position over the years. Although foreign banks have a very large presence, representing $40 \%$ of the total (BIS, 2010), the international financial crisis has not seriously affected the region's banking sector (ECLAC, 2012, p. 144). Financial innovations and the deregulation processes themselves have been implemented cautiously, to avoid the critical experiences of the financial and banking debacles that have occurred in the last few decades. This is considered an intrinsic strength of the region's financial systems (Marshall, 2011).

In the telecommunications sector, Brazil and Spain are the network's most central countries, according to their total degree centrality, followed by Mexico, Portugal and Argentina. Brazil leads in terms of in-degree centrality, and Spain in terms of out-degree centrality. In the 1990s, telecommunication firms in Latin America were essentially public-sector monopolies with major infrastructure and service quality deficiencies, stemming from the lack of financing during the "lost decade." Capital account liberalization and legislative changes, in conjunction with privatization processes, enticed foreign firms into the region, from both Europe and the United States. Yet the new century surprised the sector with a major technological crisis that triggered a profound restructuring of the business, and the universalization of Internet use in civilian life. This transformed the importance of the services provided, such that fixed-line telephony has lost ground to mobile telephony and data transmission.

7 ECLAC (2012, p. 130) contains details of the most important acquisitions in 1990-2011. 
Some of the United States firms sold their assets, prioritizing investments in the national market, and the resulting opportunities were exploited by the Spanish operator Telefónica, currently Movistar, and Mexico's América Móvil. Since then, although other smaller operators exist, these two large firms have disputed the Latin American telecommunications market. Both are vertically integrated enterprises that have grown with the aim of being national leaders with a clear vocation towards internationalization. The Spanish firm initially focused on the southern cone and fixed-line telephony, before later targeting the whole region and all telecommunications markets; while the Mexican firm started to expand via the larger economies (Brazil) or those that were closest (a number of Central American countries), focusing on mobile telephony (ECLAC, 2008). Brazil has been the battleground for both firms, where Movistar received support from Portugal Telecom to create Vivo, the country's largest mobile telephone operator.

\section{Conclusions and final remarks}

The analysis of network indicators leads to the following conclusions for each of the aims posed in the study:

(i) With respect to aim 1, on the analysis of the network structure of mergers and acquisitions, the following are the key results in terms of interactions between economies and the concentration of operations in a group of countries:

- The structure of the global network in 1999-2012 consists of a small group of central countries, while the others are on the periphery; in other words, some countries are highly interconnected through merger and acquisition flows, while other less interdependent countries are located on the fringe of the reorganization of productive asset ownership. An analysis of the trend during the period studied shows that the highest levels of interaction were attained during two periods, 2007-2009 and 2010-2011. This reflects the coexistence of asset acquisition strategies among firms that have traditionally been major investors in the region, such as those from Spain and the United States, and the emergence of certain Latin American countries as investors.

- Network concentration levels, measured through centralization, are highest between 2007 and 2011, which reveals the increased importance of a small group of countries in those years, compared to a more equal distribution in earlier years.

Accordingly, a central nucleus is forming of countries that participate more actively in the reorganization of Latin American assets, such that the growth of productive capital is consolidating a hard core of economies in which the majority of spillover effects and potential transformations of the production fabric are concentrated.

(ii) As regards aim 2, concerning the study of Spain's position in the merger and acquisitions network, compared to that of its potential competitors, the findings are as follows:

- An analysis of the position occupied by each country in the network reveals four types of country: those with high levels of total centrality, either as investor countries or as recipients, which clearly include Brazil, the United States and Mexico; (ii) those, such as Spain, that occupy a central position in the network owing to their major role as investors; (iii) those that have a central position as a result of asset sales, such as Argentina, albeit with a very clear trend of diminishing importance over the years, and (iv) those that are on the fringe of the network, scarcely connected with the central countries of the periphery and united by very weak links.

- $\quad$ Spain has maintained central positions in the network, particularly in the periods 1999-2000 and 2003-2004. The emergence of new competitors has not pushed it to the periphery, although it 
has meant a transformation of the network structure, owing to the larger number of countries in central positions.

- $\quad$ Countries that are able to compete with Spain for the central network positions include Brazil in particular, owing to its capacity to attract investment and its increasing strength as an investor country, especially since 2007. Firms from the United States have taken over Latin American enterprises throughout the period, but that country's in-degree centrality has also increased since 2007, which shows that trans-Latin firms are acquiring assets in that economy. Colombia and Chile also stand out, although to a lesser extent, as recipients of investment through the transfer of assets to foreign hands, while their firms have also been internationalizing in recent years, targeting neighbouring economies in particular. Lastly, China was very active in 2010-2011 as an investor country, with many of its firms seeking raw materials abroad to fuel national economic growth.

Accordingly, the conclusion is that Spain is maintaining its position at the centre of the network, although with growing and powerful competitors, including Brazil and United States, and probably China in the near future.

(iii) Lastly, the analysis of the sectoral networks structure (aim 3) leads to the following conclusions:

- Countries display greater interactions in the energy and finance sector networks than in telecommunications.

- $\quad$ The sectoral networks are less concentrated than the overall network. Nonetheless, whereas in the finance sector there are larger differences between the in-degree centrality index and out-degree centrality, in the cases of telecommunications and energy, the two concentrations are similar.

Substantial differences therefore exist between the sectoral networks, with greater interactions in the energy and finance sectors. Power is less concentrated in the sectoral networks than in the global one.

To summarize, the network structure of business mergers and acquisitions in Latin America shows the existence of a central core of countries that account for the bulk of asset purchase operations and, consequently, have greater access to the production of knowledge spillovers, technology transfer or learning of new forms of business organization. This means that many countries remain on the periphery of the network. Spain continues to hold central positions, albeit with powerful competitors.

\section{Bibliography}

Aitken, B.J. and A.E. Harrison (1999), "Do domestic firms benefit from direct foreign investment? Evidence from Venezuela", American Economic Review, vol. 89, No. 3, Nashville, Tennessee, American Economic Association. Álvarez, I. and C. Torrecillas (2013), "Factores determinantes de la emisión de inversión extranjera directa", Revista de Economía Mundial, No. 34, Huelva, World Economy Society.

Amir, R. and N. Lazzati (2011), "Network effects, market structure and industry performance", Journal of Economic Theory, vol. 146, No. 6, Amsterdam, Elsevier.

Bearman, P., J. Moody and K. Stovel (2004), "Chains of affection: the structure of adolescent romantic and sexual networks", American Journal of Sociology, vol. 110, No. 1.

BIS (Bank for International Settlements) (2010), "Long-term issues in international banking", CGFS Paper, No. 41, Basel, Committee on the Global Financial System.

Blomström, M. and A. Kokko (2003), "The economics of foreign direct investment incentives", Foreign Direct Investment in the Real and Financial Sector of Industrial Countries, H. Heinz Herrmann and R. Lipsey, Berlin, Springer.

Bonacich, P. (1972), "Factoring and weighting approaches to clique identification", Journal of Mathematical Sociology, vol. 2, No. 1, Taylor \& Francis. 
Calvó-Armengol, A. and M. Jackson (2004), "The effects of social networks on employment and inequality", American Economic Review, vol. 94, No. 3, Nashville, Tennessee, American Economic Association.

Casson, M.C. (1985), "The theory of foreign direct investment", The Economic Theory of the Multinational Enterprise, P.J. Buckley and M. Casson, London, Macmillan. (1979), Alternatives to the Multinational Enterprise, London, Macmillan.

Caves, R.E. (1982), "Investment, and location policies of multinational companies", Zeitschrift für Volkswirtschaft und Statistik, No. 3.

(1980), Multinational Enterprise and Economic Analysis, Cambridge, Massachusetts, Cambridge University Press.

(1971), "International corporations: the industrial economics of foreign investment", Economica, vol. 38, No. 149, Wiley.

Caves, R. and R.C. Hirschey (1981), "Research and transfer of technology by multinational enterprises", Oxford Bulletin of Economics an Statistics, vol. 43, No. 2, Oxford, Basil Blackwell.

Chinazzi, M. and others (2013), "Post-mortem examination of the international financial network", Journal of Economic Dynamics and Control, vol. 37, No. 8, Amsterdam, Elsevier.

De Benedictis, L. and others (2013), "Network analysis of world trade using the BACI-CEPII dataset", CEPII Working Paper, No. 24.

Dunning, J.H. (2009), "Location and the multinational enterprise: a neglected factor?, Journal of International Business Studies, vol. 40, No. 1, Palgrave Macmillan.

(1994), "Re-evaluating the benefits of foreign direct investment", Transnational Corporations, vol. 3, No. 1 , Geneva, United Nations Conference on Trade and Development (UNCTAD).

(1988), "The eclectic paradigm of international production: a restatement and some possible extension", Journal of International Business Studies, vol. 19, No. 1, Palgrave Macmillan.

(1980), "Toward an eclectic theory of international production", Journal of International Business Studies, vol. 11, No. 1, Palgrave Macmillan.

(1979), "Explaining changing patterns of international production: in defence of the eclectic theory", Oxford Bulletin of Economic and Statistics, vol. 41, No. 4, University of Oxford.

(1977), "Trade, location of economic activity and MNE: a search for an eclectic approach", The International Allocation of Economic Activity, B. Ohlin, P.O. Hesselborn and P.J. Wiskman (eds.), London, Macmillan.

ECLAC (Economic Commission for Latin America and the Caribbean (2014), Foreign Direct Investment in Latin America and the Caribbean, 2013 (LC/G.2613-P), Santiago. (2012), Foreign Direct Investment in Latin America and the Caribbean, 2011 (LC/G.2538-P), Santiago. (2011), Foreign Direct Investment in Latin America and the Caribbean, 2010 (LC/G.2494-P), Santiago. (2008), Foreign Direct Investment in Latin America and the Caribbean, 2007 (LC/G.2360-P), Santiago. (2005), Foreign Direct Investment in Latin America and the Caribbean, 2004 (LC/G.2447-P), Santiago. (2004), Foreign Direct Investment in Latin America and the Caribbean, 2003 (LC/G.2226-P), Santiago. (2003), Foreign Direct Investment in Latin America and the Caribbean, 2002 (LC/G.2198-P), Santiago.

Elliott, M., B. Golub and M. Jackson (2014), "Financial networks and contagion" [online] http://www.its. caltech.edu/ melliott/papers/financial_networks.pdf.

Fagiolo, G., J. Reyes and S. Schiavo (2009), "The world-trade web: topological properties, dynamics, and evolution", Physical Review E, vol. 79, American Physical Association.

Fleming, L., C. King and A. Juda (2007), "Small worlds and regional innovation", Organization Science, vol. 18, No. 6.

Galaso, P. (2011), "El papel del capital social en el desarrollo. Un estudio de las redes de innovación en España", Nuevos enfoques del desarrollo. Una mirada desde las regiones, L. Gutiérrez and M. Limas (coords.), Ciudad Juárez, Autonomous University of Ciudad Juárez.

Haberly, D. and D. Wojcik (2013), "Regional blocks and imperial legacies: mapping the global offshore FDI network", Working Papers in Employment, Work and Finance, No. 13-07, University of Oxford.

Hymer, S.H. (1979), The Multinational corporation, Cambridge, Massachusetts, Press Syndicate of University of Cambridge.

(1976), The International Operations of National Firm: a Study of Direct Foreign Investment, Cambridge, Massachusetts.

Jackson, M. (2008), Social and Economic Networks, Princeton, Princeton University Press.

Jackson, M. and A. Wolinsky (1996), "A strategic model of social and economic networks", Journal of Economic Theory, vol. 71, No. 1, Amsterdam, Elsevier. 
Kali, R. and J. Reyes (2006), "The architecture of globalization: a network approach to international economic integration", Journal of International Business Studies, vol. 38, No. 4, Palgrave Macmillan.

Kindleberger, C. (1969), American Business Abroad. Six Lectures on Direct Investment, New Haven, Yale University Press.

Luo, Y. and R. Tung (2007), "International expansion of emerging market enterprises: a springboard perspective", Journal of International Business Studies, vol. 38, No. 4, Palgrave Macmillan.

Maldonado, P. and R. Palma (2004), "Seguridad y calidad del abastecimiento eléctrico a más de 10 años de la reforma de la industria eléctrica en países de América del Sur", Recursos Naturales e Infraestructura series, No. 72 (LC/L.2158-P), Santiago, Economic Commission for Latin America and the Caribbean (ECLAC).

Marshall, E. (2011), "Desarrollo financiero en América Latina: avances y desafíos", Economic Policy Papers, No. 43, Santiago, Central Bank of Chile.

Mathews, J.A. (2006), "Dragon multinationals: new players in 21st century globalization", Asia Pacific Journal of Management, vol. 23, No. 1, Springer.

Mitchell, M. and A. Skrzypacz (2006), "Network externalities and long-run market shares", Economic Theory, vol. 29, No. 3, Springer.

Moon, H. and T.W. Roehl (2001), "Unconventional foreign direct investment and the imbalance theory", International Business Review, vol. 10, No. 2, Amsterdam, Elsevier.

Rodrik, D. (2011), The Globalization Paradox. Democracy and the Future of the World Economy, New York, W.W. Norton \& Company, Inc.

Rugman, A.M. (1981), Inside the Multinationals: the Economics of Internal Markets, New York, Columbia University Press.

(1980), "Internationalization as a general theory of foreign direct investment: a re-appraisal of the literature", Weltwirtschafliches Archiv, vol. 116.

(1976), "Risk reduction by international diversification", Journal of International Business Studies, vol. 7 , No. 2, Palgrave Macmillan.

Sánchez Díez, A. (2002), La internacionalización de la economía española hacia América Latina: los elementos determinantes en el inicio y la consolidación del proceso, Burgos, University of Burgos.

Schilling, M.A. and C.C. Phelps (2007), "Interfirm collaboration networks: the impact of large-scale network structure on firm innovation", Management Science, vol. 53, No. 7.

Stanley, L. (2004), "Acuerdos bilaterales de inversión y demanda ante tribunales internacionales: la experiencia argentina reciente", Desarrollo Productivo series, No. 158 (LC/L.2181-P), Santiago, Economic Commission for Latin America and the Caribbean (ECLAC).

Tecee, D.J. (1986), "Transactions cost economics and the multinational enterprise", Journal of Economic Behaviour of Organization, vol. 7, No. 1, Amsterdam, Elsevier.

Teece, D., G. Pisano y A. Shuen (1997), "Dynamic capabilities and strategic management", Strategic Management Journal, vol. 18, No. 7.

UNCTAD (United Nations Conferene on Trade and Development) (n/d), UNCTADSTAT [online] http://unctadstat. unctad.org/EN/Index.html.

Visintin, S. (2011), "A network approach to services internationalization", paper presented at the XIV Meeting of Applied Economics, Huelva, University of Huelva.

Vitali, S., J.B. Glattfelder and S. Battiston (2011), "The network of global corporate control", PLoS ONE, vol. 6, No. 10.

Vitali, S. and S. Battiston (2013), "The community structure of the global corporate network" [online] https:// arxiv.org/pdf/1301.2363v1.pdf.

Wasserman, S. and K. Faust (1994), Social Network Analysis. Methods and Applications, Cambridge, Cambridge University Press.

Watts, D. and S. Strogatz (1998), "Collective dynamics of 'small-world' networks", Nature, vol. 393.

Williamson, O.E. (1975), Markets and Hierarchies: Analysis and Antitrust Implications. A Study of the Economics of Internal Organization, New York, Free Press.

Zabalo Arena, F. (2012), "América Latina ante las demandas inversor-Estado", Revista de Economía Mundial, No. 31, World Economy Society. 